\title{
Climate in the Pleistocene
}

SIR - White et al. ${ }^{1}$ proposed a novel method of reconstructing Pleistocene atmospheric $\mathrm{CO}_{2}$ concentrations based on the stable carbon isotope composition $\left(\delta^{13} \mathrm{C}\right)$ of mosses and sedges from peat cores. Their technique exploits differences in environmental control over $\delta^{13} \mathrm{C}$ values in tissues of $\mathrm{C} 3$ vascular plants and mosses. For mosses, they assume that variation in water content above that required for maximum photosynthesis does not alter $\delta^{13} \mathrm{C}$ values. However, because diffusivity is four orders of magnitude lower in water than in air, external water films create large barriers to carbon assimilation in mosses and fluctuations in water content do significantly influence carbon isotope discrimination.

In the moss genus Sphagnum, photosynthetic rates are highly dependent on plant water content. At low water contents, dehydration inhibits photosynthesis, whereas when plants are highly saturated, photosynthesis declines by as much as $50 \%$ due to water films $\mathrm{s}^{2-5}$. Variation in water content alters internal $\left[\mathrm{CO}_{2}\right]$ and should directly influence carbon isotope discrimination $\Delta$.

We used on-line measurements of $\Delta$ to assess the consequences of variation in

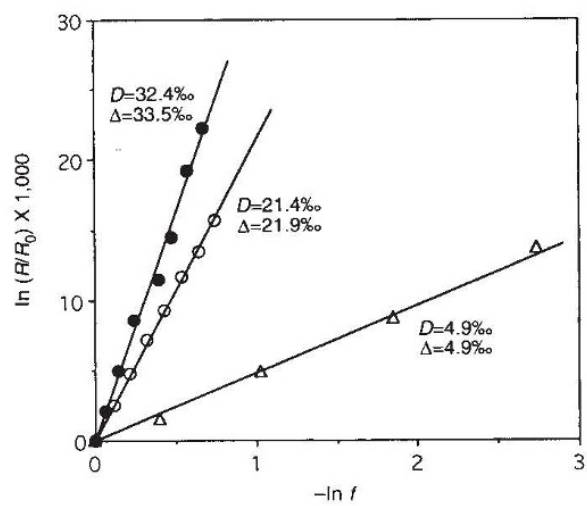

On-line measurements of carbon isotope discrimination $\Delta$. Water films in wet (open circles; $38 \mathrm{~g} \mathrm{H}_{2} \mathrm{O}$ dry $\mathrm{wt}^{-1}$ ) plants increase resistance to $\mathrm{CO}_{2}$ uptake and cause a decline in carbon isotope discrimination $\Delta$ when compared with dry plants (closed circles; $23 \mathrm{~g} \mathrm{H}_{2} \mathrm{O}$ $\mathrm{g}$ dry $\left.w t^{-1}\right)$. The wet $\left(r^{2}=1.000\right)$ and dry $\left(r^{2}=0.996\right)$ measurements shown are near the mean values for these treatments (see table). The discrimination factor $(D)$ is the slope of the linear regression of In $\left(R / R_{0}\right)$ versus - In $f$ through the origin ${ }^{9}$, where $f$ is the fraction of the original $\mathrm{CO}_{2}$ in the reaction chamber and $R_{\mathrm{o}}$ and $R$ are the isotope ratios $\left({ }^{13} \mathrm{C} /{ }^{12} \mathrm{C}\right)$ of the initial and subsequent samples. The discrimination ${ }^{9}(\Delta)$ is calculated from $D$ using the equation $\Delta=D /(1-D)$. The relationship shown for maize (open triangles; $r^{2}=0.999$ ) estimates a $\Delta$ value of $4.9 \%$, within $0.5 \%$ of the expected value. Discrimination values are higher than expected for C3 plants $(\Delta=28 \%$ ) because respiration affects chamber $f$ and $R$. Details of methods are available from the authors. water content on $\Delta$ in Sphagnum magellanicum plants (see figure). An analysis of variance test $(n=4)$ revealed that water contents significantly alter $\Delta$ values (see table; $f>10.5, P<0.02)$. The mean for the wet plants (at greenhouse water content) was $8.1 \%$ lower than for the dry plants (blotted dry, but above the optimum for photosynthesis). During on-line measure-

\section{$\triangle$ VALUES FOR S. MAGELLANICUM PLANTS}

\begin{tabular}{lll}
\hline Treatment & Uncorrected $(\%)$ & $\begin{array}{l}\text { Corrected for } \\
\text { respiration }(\%)\end{array}$ \\
& mean \pm s.e. & mean \pm s.e. \\
Dry & $32.9 \pm 1.3$ & $20.7 \pm 0.8$ \\
Wet & $24.8 \pm 1.7$ & $17.3 \pm 0.7$ \\
\hline
\end{tabular}

Respiration affects $\Delta$ values in on-line discrimination studies. Corrected and uncorrected results are similar, and show that $\Delta$ values are significantly affected by changes in water content $(P<0.02)$. Mean discrimination values $\Delta$ for wet plants are 3.4-8.1\%o lower than dry ones for corrected and uncorrected data.

ments, however, respiration alters the value of $\Delta$. To estimate the maximum effect of this we assumed that all respired $\mathrm{CO}_{2}$ measured during dark respiration diffuses into the chamber before refixation. This correction establishes a lower limit for $\Delta$. The corrected mean $\Delta$ value is $9.8 \%$ o lower, but the correction factor does not affect the order of means where the wet plants had a $3.4 \%$ ower $\Delta$ value than the dry plants. These results are consistent with field $\delta^{13} \mathrm{C}$ data ${ }^{6}$.

In the field, Sphagnum plants experience 4-5-fold variation in water content caused by local effects along hummockhollow gradients and by seasonal or annual variation in rainfall ${ }^{3,4,7,8}$. These differences are correlated with $>50 \%$ variation in measurements of net carbon assimilation rates ${ }^{7,8}$. Therefore, $\delta^{13} \mathrm{C}$ values in field plant material will be greatly influenced by the local water regime because of variation in water contents. Less negative $\delta^{13} \mathrm{C}$ values will occur in plants grown at higher water potentials.

White et al. ${ }^{1}$ use variations as small as $5 \%$ in mosses from peat cores to predict past $\left[\mathrm{CO}_{2}\right]$ of the atmosphere. However, such variability could be the result of small changes in local water regimes. Their estimates agree best with $\left[\mathrm{CO}_{2}\right]$ measured from the Byrd ice core when $\delta^{13} \mathrm{C}$ values of the mosses change by $>5 \%$ o $(11,000-$ 13,000 years before present). These large fluctuations are not likely to be due to water content variation. Models that use $\delta^{13} \mathrm{C}$ values from mosses to estimate past climates need to consider the influence of water films on the total resistance to $\mathrm{CO}_{2}$ uptake and isotope discrimination. To accomplish this, $\delta^{13} \mathrm{C}$ values can be modelled as a linearly decreasing function of water content above the optimum water content for photosynthesis and as a constant below it; and water contents can be estimated from vascular plant $\delta^{13} \mathrm{C}$ values as by White et al. ${ }^{1}$.

Steven K. Rice

Larry Glles

Botany Department,

Duke University, Durham,

North Carolina 27708, USA

WHITE ET AL. REPLY - We are pleased that the change in calibration suggested by Rice and Giles does not affect our reconstruction of the large $\left[\mathrm{CO}_{2}\right]$ changes during the last glacial transition. We agree in principle with their argument, but wish to point out that field studies of $\delta^{13} \mathrm{C}$ values in mosses indicate that this effect may not be present in the down-core record at Harbeston. For reasons detailed below, we opted in our Letter ${ }^{1}$ for a simpler relationship between water content and photosynthesis, with only a suboptimal effect.

In surveys of surface Sphagnum samples from many bogs in Patagonia we have never found a correlation between hummock height and/or hollow depth and $\delta^{13} \mathrm{C}$ of mosses. This is, in fact, one of the first correlations we tried to find, based on the previous studies noted by Rice and Giles. Although the Patagonian bogs we sampled lack very large hummocks, we have sampled relief in excess of 50 centimetres and still found no $\delta^{13} \mathrm{C}$ effect.

In surveys of $\delta^{13} \mathrm{C}$ in living Sphagnum in many bogs we find that variability in modern plants can be as large as $3 \%$ in one bog. Correlations of the $\delta^{13} \mathrm{C}$ changes with water content in the mosses are not significant, although single measurements of water content may not be representative of the average growing season water content. The only correlation has been with distance from the edge of the bog, shown most stongly in small bogs with high surrounding trees. The $\delta^{13} \mathrm{C}$ values get lighter from the centres of the bogs towards the edges, perhaps indicating that mixing in the air may be slowed by the trees acting as wind screens. The isotopically light, respired $\left[\mathrm{CO}_{2}\right]$ then changes the atmospheric $\delta^{13} \mathrm{C}$ value, as well as raising the $\left[\mathrm{CO}_{2}\right]$ which acts to decrease the effect. Even if there is a masked effect of water content, it is probably less than $3 \%$.

\footnotetext{
1. White, J. W. C. et al. Nature 367, 153-156 (1994).

2. Silvola, J. Holarct. Ecol. 13, 224-228 (1990).

3. Murray, K. J., Harley, P. C.. Beyers, J., Walz, H. \& Tenhunen, J. Oecologia 79, 244-250 (1989).

4. Silvola, J. Aaltonen, H. Ann. Bot. Fenn. 21, 1-6 (1984).

5. Titus, J. E., Wagner, D. J. \& Stephens, M. D. Ecology 64 , $1109-1115$ (1983)

6. Proctor, M. C. F. Raven J. A. \& Rice, S. K. J. Bryol. 17 193-202 (1992)

7. Wallen, B, Falkengren-Grerup, U. \& Malmer, N. Holarct. Ecol. 11, 70-76 (1988)

8. Titus, J. E. Wagner, D. J. Ecology 65, 1765-1774 (1984)

9. Guy, R. D., Berry, J. A., Fogel, M. L. \& Hoering, T. C. Pl. Physiol. 101, 37-47 (1993)
} 